\title{
A software package for predicting design-flood hydrographs in small and ungauged basins
}

\author{
Rodolfo Piscopia, ${ }^{1}$ Andrea Petroselli, ${ }^{2}$ Salvatore Grimaldi ${ }^{3}$ \\ ${ }^{1}$ Freelance, Rome; ${ }^{2}$ Department of Sciences and Technologies for Agriculture, Forestry, \\ Nature, and Energy, University of Tuscia, Viterbo; ${ }^{3}$ Department for Innovation in \\ Biological, Agro-food and Forest systems, University of Tuscia, Viterbo, Italy
}

\begin{abstract}
In this study, software for estimating design hydrographs in small and ungauged basins is presented. The main aim is to propose a fast and user-friendly empirical tool that the practitioner can apply for hydrological studies characterised by a lack of observed data. The software implements a homonymous framework called event-based approach for small and ungauged basins (EBA4SUB) that was recently developed and tested by the authors to estimate the design peak discharge using the same input information necessary to apply the rational formula. EBA4SUB is a classical hydrological event-based model in which each step (design hyetograph, net rainfall estimation, and rainfall-runoff transformation) is appropriately adapted for empirical applications without calibration. As a case study, the software is applied in a small watershed while varying the hyetograph shape, rainfall peak position, and return time. The results provide an overview of the software and confirm the secondary role of the design rainfall peak position.
\end{abstract}

\section{Introduction}

Design peak discharge and hydrograph estimation are crucial for a variety of hydrological applications, specifically for hazard mapping procedures. In small basins, most available approaches are empirical.

\footnotetext{
Correspondence: Salvatore Grimaldi, Department for Innovation in Biological, Agro-food and Forest systems (DIBAF), University of Tuscia, via San Camillo De Lellis, snc, 01100, Viterbo, Italy.

E-mail: salvatore.grimaldi@unitus.it
}

Key words: Design hydrograph; design peak discharge; ungauged basins; floods, small basins.

Received for publication: 31 July 2014.

Accepted for publication: 26 April 2015.

(C) Copyright R. Piscopia et al., 2015

Licensee PAGEPress, Italy

Journal of Agricultural Engineering 2015; XLVI:432

doi:10.4081/jae.2015.432

This article is distributed under the terms of the Creative Commons Attribution Noncommercial License (by-nc 3.0) which permits any noncommercial use, distribution, and reproduction in any medium, provided the original author(s) and source are credited.
Indeed, a small basin $\left(<500 \mathrm{~km}^{2}\right)$ is usually ungauged and is lacking hydrometric observations; it may also lack rainfall information, making it inappropriate for physically based models.

Recently, the scientific community (Sivapalan et al., 2003; Bloschl et al., 2013; Hrachowitz et al., 2013) has vigorously identified advanced procedures for optimising the few available observations. However, for particular small basins for which it is not possible to apply regionalisation techniques, the practitioner must adopt empirical methods that do not require calibration procedures.

In such cases, the most preferred approach is the rational formula (Mulvaney, 1851; Chow et al., 1988; Kuichling, 1889):

$$
Q_{p}=C \frac{h_{c}}{T_{c}} A
$$

where $Q_{p}$ is the peak discharge, $C$ is the runoff coefficient, $h_{c}$ is the critical gross rainfall, $T_{c}$ is the critical rainfall duration equal to the basin concentration time and $A$ is the watershed area. This formula allows for an estimation of the peak discharge with an assigned return period $T_{r}$ but not for an estimation of the design hydrograph, which is usually evaluated starting at the peak discharge value; empirical equations are used for the rising and recession limbs, modifying the critical design volume (Autorità di Bacino del Fiume Tevere, 2006).

The success of the rational formula is due to its simplicity and to the minimal information that the practitioner needs to apply it. However, this approach suffers some drawbacks. The main concern is related to the runoff coefficient $C$. Indeed, this parameter is arbitrary because it refers to empirical tables that were not calibrated using experimental tests but through consultation of experts (Dhakal et al., 2012) who suggest a range of possible values based on the soil use and type. The second issue is related to the concentration time. This parameter has a strong influence on the formula, although it is well known that its estimation is affected by large uncertainty (up to $500 \%$, see Grimaldi et al., 2012b).

Recently, the authors have proposed, developed, and tested an event-based framework for design hydrograph estimation that can be applied for the same complex conditions in which the rational formula is adopted. The proposed model (Grimaldi and Petroselli, 2015; Petroselli and Grimaldi, 2015) is called the event-based approach for small and ungauged basins (EBA4SUB). The model consists of a series of modules that are typical of event-based procedures: design gross rainfall estimation, design hyetograph selection, net rainfall estimation, and rainfall-runoff transformation.

As underlined in the author contributions, the aim of EBA4SUB is not to provide a more accurate estimation of the design hydrograph but to make available an empirical tool that minimises the roles of parameter sensitivity and subjectivity and of the practitioner. We are aware that a hydrological analysis based on a limited set of informa- 
tion cannot provide good results when compared with observations; however, it could provide the most realistic and objective results possible. Practically, the main aim of the EBA4SUB model is to reduce the degree of freedom related to both the runoff coefficient and concentration time, proposing a framework that provides similar results when it is applied by two analysts at different times for the same watershed and input data.

This work aims to introduce and apply the EBA4SUB software while implementing the homonymous framework, which is simple and fast. In the next section, the model is described to illustrate the input parameters. In Section 3, the software and all practical details are fully described. Prior to the conclusions section, a case study is conducted on the Lagarello watershed by varying parameters in the software.

\section{The EBA4SUB framework}

As described in the Introduction, the EBA4SUB model is an eventbased procedure that is optimised for ungauged basins. The minimal information necessary for its application is: i) intensity-duration-frequency curves (IDF, with two parameters) for the analysed basin; ii) a digital elevation model; and iii) soil use and type.

Compared with the common version of rainfall-runoff models, the novel contributions presented by EBA4SUB are mainly related to the net rainfall estimation module and to the rainfall-runoff transformation. Next, all the framework steps, which are fully described in Grimaldi and Petroselli (2015), are summarised.

\section{Design hyetograph}

In the literature, several design synthetic hyetographs are available; among these, the Chicago equation seems to be the most accurate (Keifer and Chu, 1957; Alfieri et al., 2008).

Assuming that an IDF with two parameters is suitable, the Chicago equations are as follows:

$$
\begin{aligned}
& i\left(t, T_{r}\right)=a\left(T_{r}\right) n\left(T_{r}\right)\left(\frac{t_{p}-t}{r_{c}}\right)^{n-1} \text { for } t \leq t_{p} \\
& i\left(t, T_{r}\right)=a\left(T_{r}\right) n\left(T_{r}\right)\left(\frac{t-t_{p}}{1-r_{c}}\right)^{n-1} \text { for } \quad t>t_{p}
\end{aligned}
$$

where $i$ is the rainfall intensity, $t$ is the time, $T_{r}$ is the return period, $a$ and $n$ are the IDF coefficients, $t_{p}$ is the peak time and $r_{c}$ is the ratio between the peak time and rainfall duration.

To apply Equation (2), the return period $T_{r}$ and a critical duration (equal to the concentration time $T_{c}$ here) must be assigned. Regarding the $r_{c}$ parameter, previous analyses have shown that is not particularly sensitive, so the mean value $r_{c}=0.5$ is suggested for practical applications (Petroselli and Grimaldi, 2015).

To refine the design rainfall estimation, the areal reduction factor (ARF) should eventually be applied to extend to the whole basin the punctual raingauge information (Leclerc and Schaake, 1972):

$$
A R F=\frac{A R}{P R}=1-e^{\left(-1.1^{*} t^{0.25}\right)}+e^{\left(-1.1^{*} t^{0.25}-0.0259 A\right)}
$$

where $A R$ represents the cumulative areal rainfall $(\mathrm{mm}), P R$ is the rain gauge cumulative value (mm) obtained from the IDF, $t$ is the rainfall duration (h) and $A$ is the watershed dimension $\left(\mathrm{km}^{2}\right)$.

The Chicago hyetograph has positive and negative aspects. A negative aspect is the intrinsic tendency to overestimate the rainfall because it represents the critical rainfall for all partial durations of the event. However, this peculiarity could have a positive implication if the practitioner is aware that the obtained hyetograph is an upper threshold that favours safety. Notably, regarding the same peculiarity, $T_{c}$ has a minimum impact on the design hyetograph estimation because it only affects the total amount of the gross rainfall and not the maximum intensity that is equal to the IDF value related to the discretised temporal resolution.

\section{Net rainfall}

The net hyetograph is estimated by applying a procedure that was recently proposed by the authors (Grimaldi et al., 2013a, 2013b); the procedure is based on the curve number (CN) method and on the Green-Ampt equation (GA) called the curve number for Green Ampt (CN4GA). In practice, we assume that the $\mathrm{CN}$ method is generally correct, as it is derived from extensive experimental calibration and widely applied in the literature. However, the $\mathrm{CN}$ approach cannot be applied for studying rainfall events at the sub-daily time scale (Woodward et al., 2010), and this is the reason of the jointly application of the GA equation. The proposed method consists of two consecutive steps. The first step estimates the total net rainfall by appropriately using the $\mathrm{CN}$ formula (NRCS, 2008):

$$
\begin{array}{lll}
P_{e}=\frac{\left(P-I_{a}\right)^{2}}{P-I_{a}+S} & \text { if } & P>I_{a}=\lambda S \\
P_{e}=0 & \text { if } & P \leq I_{a}
\end{array}
$$

where $P_{e}$ is the total net rainfall (mm), $P$ is the total gross rainfall $(\mathrm{mm}), I_{a}$ is the initial abstraction $(\mathrm{mm}), \lambda$ is the fraction of the initial losses (equal to 0.2 according to the original formulation; if the practitioner uses the original tables, then this value cannot be modified), and $S$ is the potential retention $(\mathrm{mm})$ related only to the $\mathrm{CN}$ value.

The second step temporally distributes the total net rainfall amount using the GA equation (Green and Ampt, 1911; Mein and Larson, 1973):

$$
\begin{array}{lll}
q_{0}(t)=i(t) & \text { for } & t<t_{p} \\
q_{0}(t)=K_{s}\left(1+\frac{\Delta \theta \Delta H}{I(t)}\right) & \text { for } & t>t_{p}
\end{array}
$$

where $q_{0}$ is the infiltration rate, $i$ is the rainfall intensity, $I$ is the cumulative infiltration, $K_{s}$ is the saturated hydraulic conductivity, $t_{p}$ is the ponding time, $\Delta H=h_{f}-h_{\text {surf }}$ is the difference between the matric pressure head along the moving wetting front $\left(h_{f}\right)$ and at the soil surface ( $h_{\text {sur }}$, generally $\left.=0\right)$, and $\Delta \theta$ is the change in the soil water content $\left(\theta_{s}\right.$ - $\theta_{i} ; \theta_{s}$ is the field saturated soil water content; $\theta_{i}$ is the initial value of the soil water content). 
Equation (5) is implemented by assuming that the ponding time is reached when the total precipitation from the beginning of the event is equal to $I_{a}$. The calibration of parameters in Equation (5) is automatically performed by matching the cumulative net rainfall values computed by Equations (5) and (4). Previous studies showed that, in the case of rainfall events characterised by a prominent peak, the parameters included in Eq. (5) are practically insensitive; accordingly, default values related to the average soil type can be assigned (Grimaldi et al., 2013a).

In practice, this step requires the evaluation of only one parameter, the $\mathrm{CN}$, which can be quantified using Natural Resources Conservation Service (NRCS) tables. The CN value is classified by considering the antecedent moisture conditions and the period of the rainfall event within the year (AMC I, AMC II, and AMC III), which can be varied by the analyst. Nonetheless, because such information in the event-based approach is unavailable, average conditions are recommended.

\section{Design hydrograph}

The rainfall-runoff model included in EBA4SUB is a particular version of the instantaneous unit hydrograph based on the width function (WFIUH) (Mesa and Mifflin 1986; Rinaldo et al., 1991; Giannoni et al., 2003; Boni et al., 2007; Borga et al., 2007), recently developed by the authors (WFIUH-1par) (Grimaldi et al., 2012a) and finalised for ungauged applications.

The WFIUH model is generally represented by the equation:

$$
\operatorname{WFIUH}(t)=\frac{L_{c}(x)}{v_{c}(x)}+\frac{L_{h}(x)}{v_{h}(x)}
$$

which describes the time distribution of the concentration of all digital elevation model (DEM) cells to the outlet. $L_{c}$ and $L_{h}$ are the drainage paths along the channel and hillslope, respectively, related to the DEM cell $x$ of the watershed. $v_{c}$ and $v_{h}$ are the assumed velocities along the channel and hillslope.
To identify the drainage length related to each DEM cell, algorithms should be applied to estimate the flow directions and to automatically extract the drainage network by selecting the channel and hillslope cells (Nardi et al., 2008). The only parameter to be assigned is the area threshold for which a cell can be flagged as a channel. Fortunately, the effects of the variation in this parameter are limited; consequently, a value in the range 0.5 and $1 \mathrm{~km}^{2}$ can be adopted; as default value, we choose $0.5 \mathrm{~km}^{2}$.

Equation (6) is a common WFIUH version, and the peculiarity of the WFIUH-1par model lies in estimating/assigning the $v_{c}$ and $v_{h}$ velocity values. The hillslope velocities are estimated cell by cell in a distributed manner using an empirical formula related to the slope and soil use (Grimaldi et al., 2010). Consequently, the only parameter to be assigned is the channel velocity, which is calibrated by assuring that the centre of the WFIUH mass is equal to the basin lag time $\left(T_{L}\right)$ that is estimated proportionally to the concentration time $T_{L}=0.6 T_{c}$.

WFIUH-1par has a meaningful advantage: it identifies the IUH shape using detailed geomorphological information included in the DEM concerning either the drainage path distribution or the hillslope velocity estimation.

When observations are available, the channel velocity can easily be calibrated. In the present ungauged condition, it is necessary to refer to the concentration time (through the lag time). However, when using $T_{L}$, the model is less sensitive to the $T_{c}$ variability (Grimaldi and Petroselli, 2015).

\section{The EBA4SUB software}

The software is designed using two screenshots: one for the input and one for the output. When an analyst launches EBA4SUB, the screenshot shown in Figure 1 appears. Before detailing the input descriptions, it is useful to briefly outline the output screenshot

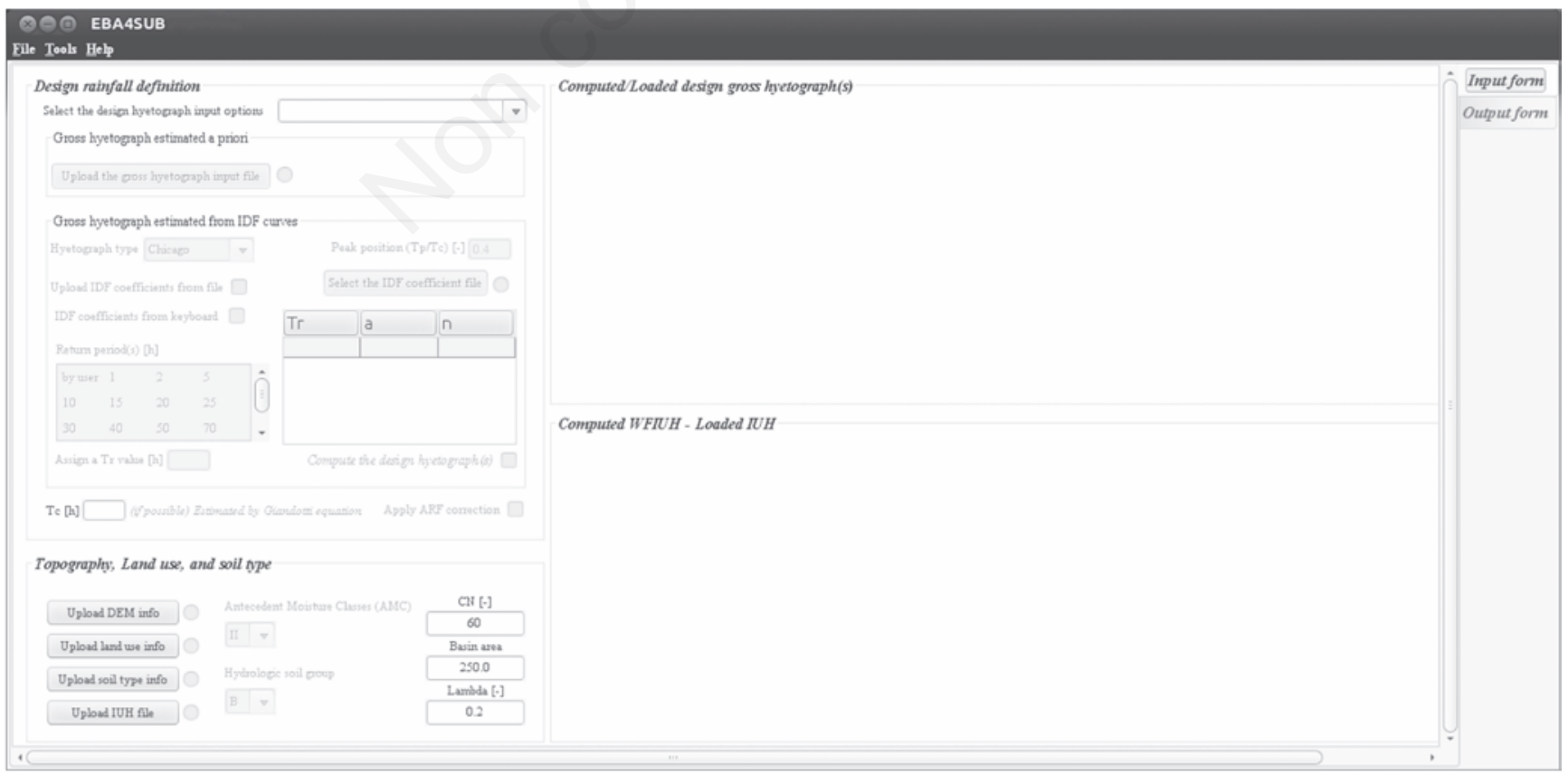

Figure 1. EBA4SUB - Input screenshot. 
(Figure 2), which comprises two parts: the upper screen, in which the net hyetograph design is shown and all parameter values, assigned and estimated by the model, are resumed; the lower screen, in which the design hydrograph is plotted with a summary of the parameter values.

The input data sheet is designed by homogeneous groups of parameters; on the upper left side, it is necessary to specify the gross hyetograph parameters (the software permits simultaneously solving of several rainfall events for the same watershed). On the lower left side, it is possible to assign topographic and soil characterisation parameters. Between the two data sheet components, there is a box for assigning the concentration time value; if the watershed topography is uploaded, then the software estimates $T_{c}$ by the Giandotti formula.

Finally, on the right side of the data sheet, there are two plots (Figure 3) that illustrate the mid-step results: the gross hyetograph (upper plot) and the WFIUH-1par function (lower plot). When clicking on the plots using the right mouse button, a small window will appear that presents actions, including the option to export the graph in several file formats and the plot data in ASCII format. The same options are available for the plot in the output screenshot.

The input parameter set needed for the hyetograph definition is

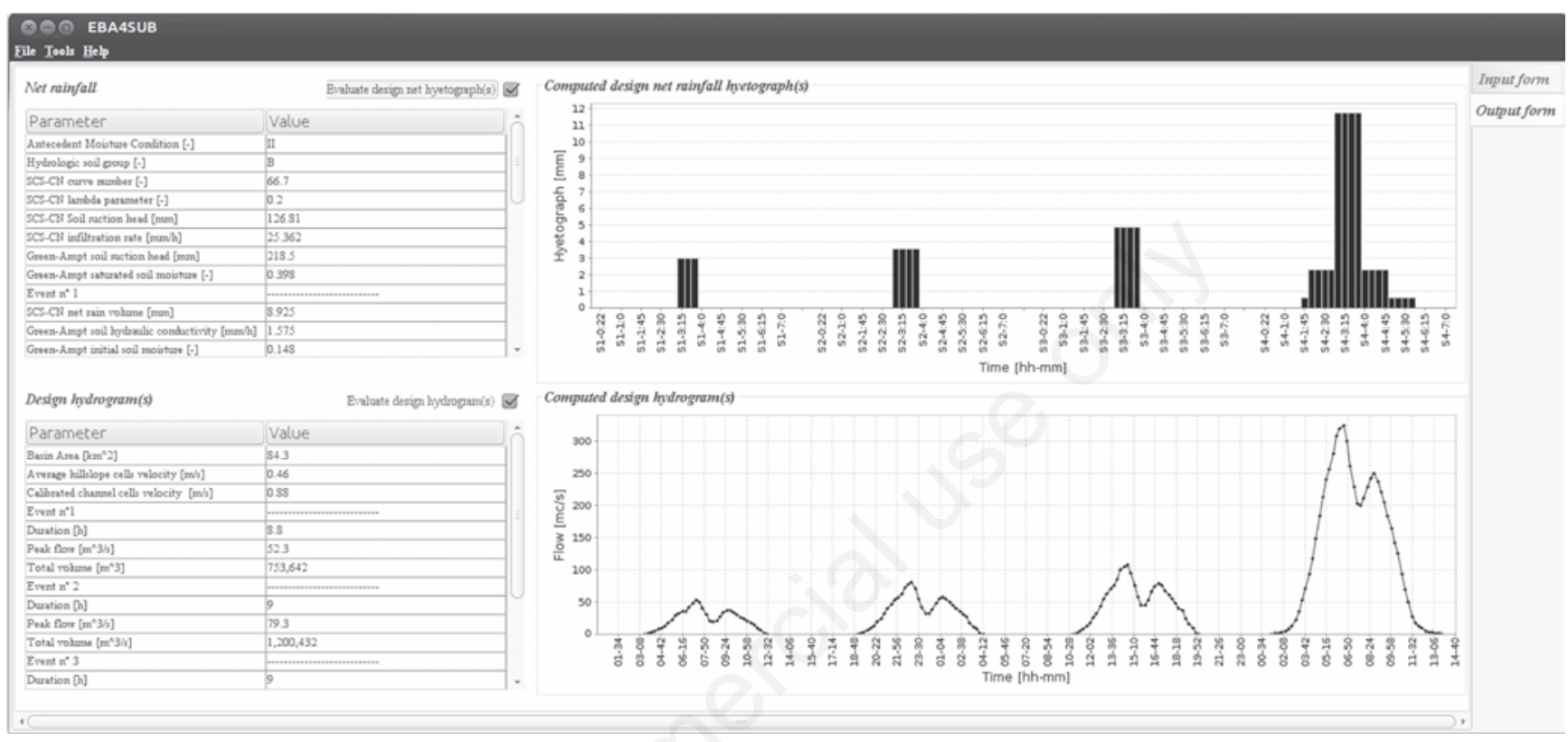

Figure 2. EBA4SUB - Output screenshot.

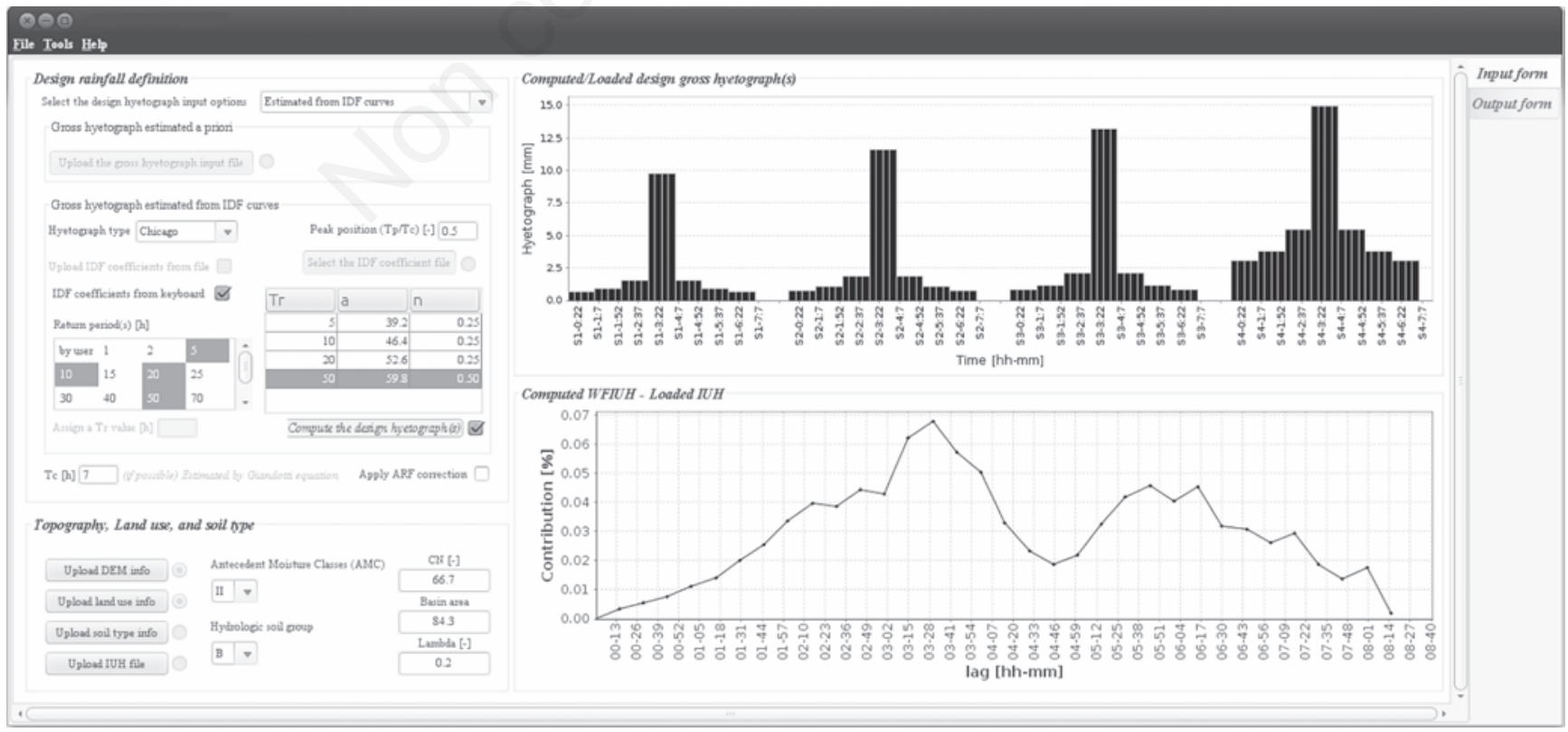

Figure 3. EBA4SUB - Input data sheet with temporary results: gross hyetograph and the instantaneous unit hydrograph based on the width function (WFIUH) function. 
organised as follows (Figure 4). In the upper combo-box, the input method of uploading a text file with hyetograph data or estimating the gross hyetograph using the IDF parameters is provided. In the first case, a button just below the combo-box is activated, allowing for the selection of a two-column ASCII file; a null rainfall value represents a break in the time series between separate rainfall events. In the second case, the gross hyetograph is estimated by specifying the concentration time, the hyetograph type (rectangular, triangular, and Chicago are included), the rainfall peak position, and the IDF coefficients. These latter options can be selected in two ways: either uploading a three-column ASCII file $\left(T_{r}, a, n\right)$ or typing from the keyboard. In the first case (Figure 5), after displaying the values in the dedicated table, the hyetograph estimation is performed as soon as the concentration time value is specified. Notably, the ARF correction is applied to the rainfall only after that the gross hyetograph has been estimated (its application is eventually reversible).

In the second case, the IDF return periods (eventually with multiple selection) can be chosen on the prefilled table, as shown in Figure 6.

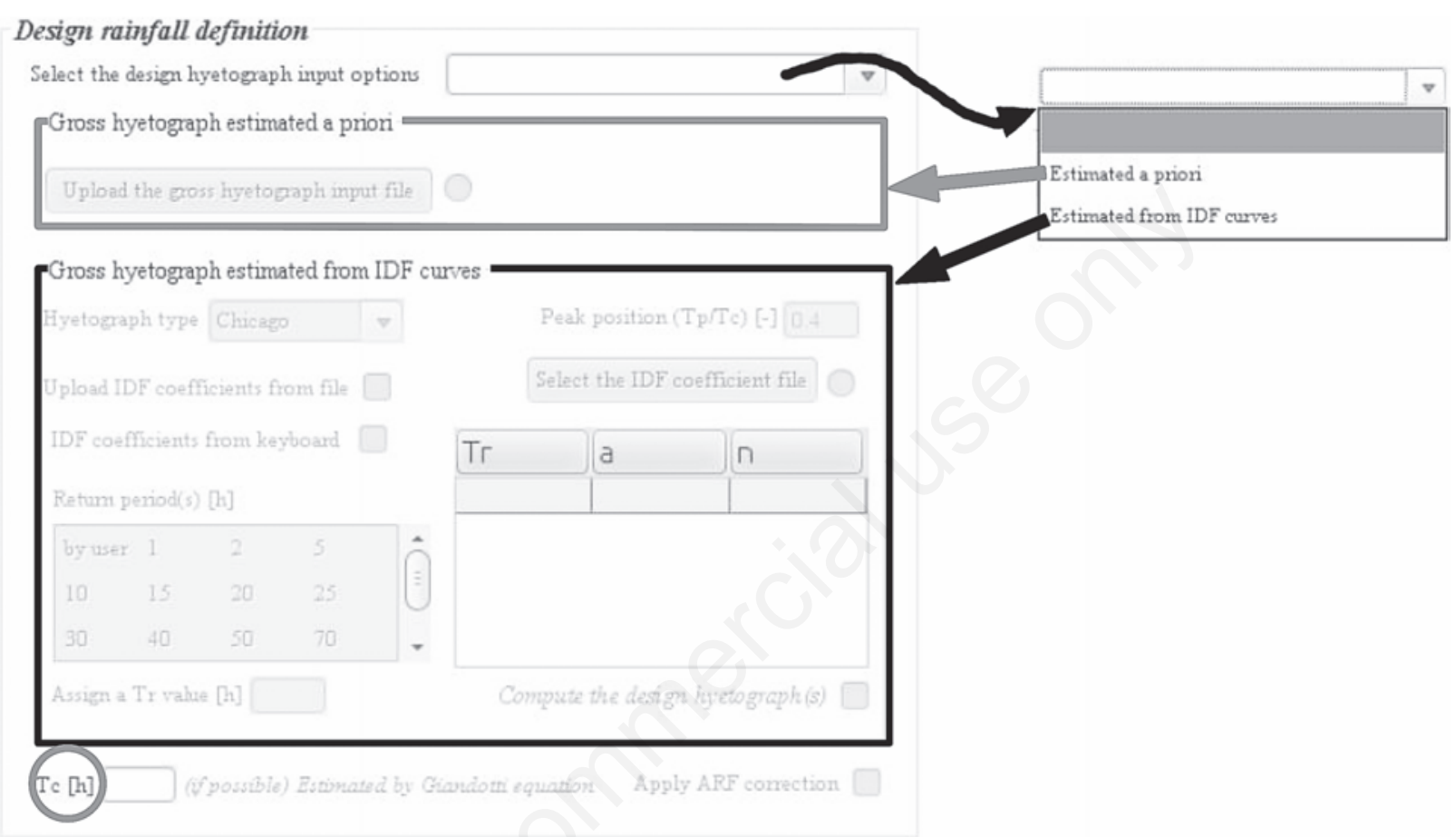

Figure 4. EBA4SUB - Input data for defining the gross hyetograph.

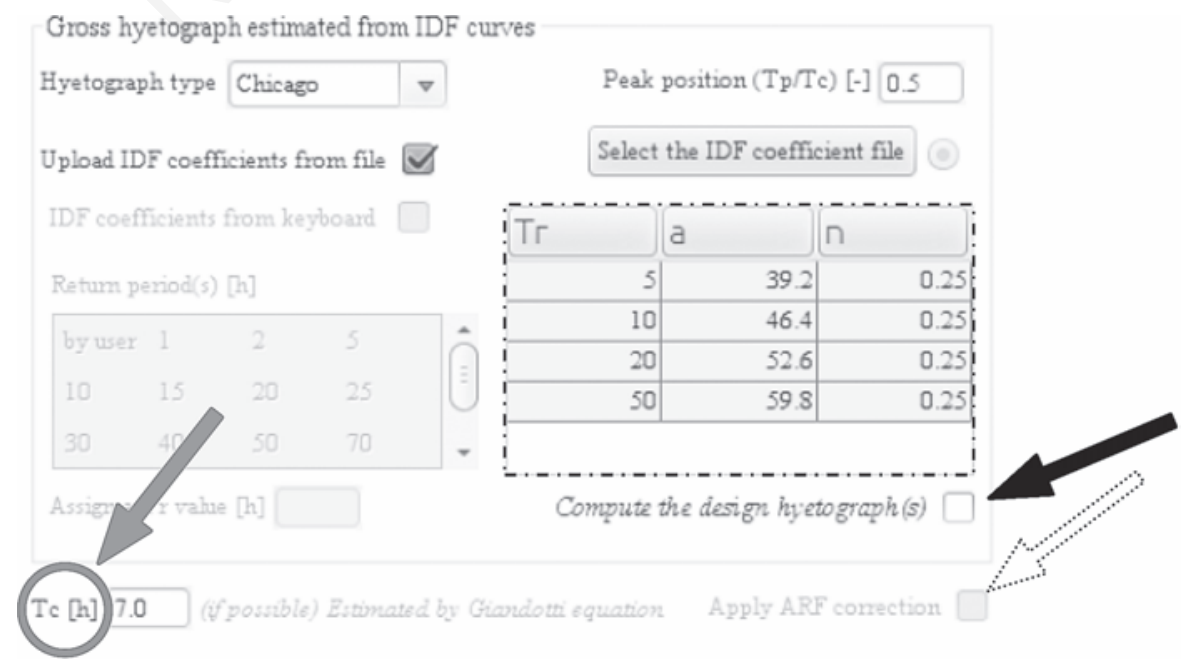

Figure 5. EBA4SUB - Intensity-duration-frequency curves (IDF) parameter upload using an ASCII file and gross hyetograph estimation. 
Later, the cells related to the corresponding $a$ and $n$ values should be filled in. In this case, it is necessary to evaluate the gross hyetograph, and the ARF correction can be applied afterward. In case the desired return period is not included in the prefilled table, the analyst can select the cell by user to activate the text field where a specific $T_{r}$ value can be assigned.

Given the details on gross rainfall analysis, it is necessary to explain how to set up the time resolution. The default value is $60 \mathrm{~min}$, and it can be changed in the general basic parameter mask (Figure 7), which can be displayed from the menu Tools. In the same mask, it is possible to also change the WFIUH time resolution, which has a default value of $15 \mathrm{~min}$.

The net hyetograph and WFIUH should have the same time resolution for convolution. For the rainfall data, in contrast to WFIUH, a onehour resolution is a good compromise. Actually, for a small basin and short concentration time, only a few steps would be available for WFIUH, which would not be representative of the geomorphology of the watershed. EBA4SUB allows the analyst flexibility in adopting two time resolutions (higher for WFIUH) and in adapting the rainfall sub-discretisation of the hyetograph using a uniform distribution. Figure 8 shows the different configurations that can be realised for each threeparameter set $\left(T_{r}, a, n\right)$.

Regarding the watershed soil parameters necessary for net rainfall estimations, as previously mentioned, the first step is to quantify the $\mathrm{CN}$ and $\lambda$ value to define the total net rainfall and the initial abstraction. The default value for $\lambda$ is 0.2 . With soil use information, e.g., CORINE land cover (CLC) maps, it is possible to evaluate the $\mathrm{CN}$ values of each DEM cell using NRCS tables (NRCS, 2008).

By uploading the land use maps (Figure 9), two combo-boxes will fix the antecedent moisture conditions and soil type, and the $\mathrm{CN}$ is automatically re-evaluated.

At this point, EBA4SUB has all the information necessary to estimate the net rainfall using the cumulative value of Equation (5) with the estimated volume of equation (4). The $K_{s}$ values are varied for a fixed $\Delta \theta$ until the net rainfall volumes are equivalent. When the parameter fitting does not converge, the $\Delta \theta$ value (particularly $\theta_{\mathrm{i}}$ ) is varied, and the procedure is iteratively repeated. This step is launched by marking the box evaluate design net hyetograph in the output data sheet.

The last step for the design hydrograph estimation is the WFIUH1par evaluation. This step is initiated by either uploading a two-column ASCII file or estimating the WFIUH-1par using the watershed DEM. For the second option, the DEM should fit some specific features: i) all the cells in the watershed boundary should have no data values; ii) no cell should have an elevation lower than all the valid surrounding cells (pit), except those at the basin outlet; iii) no flat area, where the cell slope is equal to zero, should be present.

DEM pre-processing allows for an evaluation of the watershed area, slopes, hillslope cell velocities, flow directions, contributing areas, and flow length for each raster cell.

Starting with this useful information, it is possible to estimate the watershed concentration time (through the Giandotti formula, using the temporal resolution adopted in the rainfall analysis as an approximation) and the drainage network. At this point, it is possible to estimate the flow velocity raster and to evaluate the WFIUH-1par through solving Equation (6). Regarding the flow velocity, as previously mentioned, we differentiate the approach for the hillslope and channel cells. For the hillslope cells, an empirical formula based on slope and soil use is applied; for channel cells, a calibration is performed using the lag time. In terms of the hillslope velocity estimation, the combined slope and soil use can provide unrealistic values due to the empirical nature of the formula and artefacts present in the DEM. For this reason, in the basic parameter mask, the minimum and maximum values of the hillslope velocity are fixed (Figure 7: Min velocity in sloping cells; max velocity in sloping cells). When the estimated value exceeds the assigned limits, the corresponding threshold value is adopted.

It may be useful to summarise all the parameters included in the framework. Table 1 shows the list differentiating between primary and secondary parameters. Primary parameters have a dominant role in EBA4SUB; these parameters are assigned using empirical formulas or tables and are calibrated if observed rainfall-runoff events are available. Secondary parameters are nearly insensitive, with a limited effect on the output. Consequently, these parameters are assigned using the average values suggested by the literature.

\section{EBA4SUB application for the Lagarello case study}

An application of the proposed EBA4SUB software in the Lagarello watershed, Terni province, Central Italy, is described. For the selected watershed, discharge observations are not available, so the aim of the
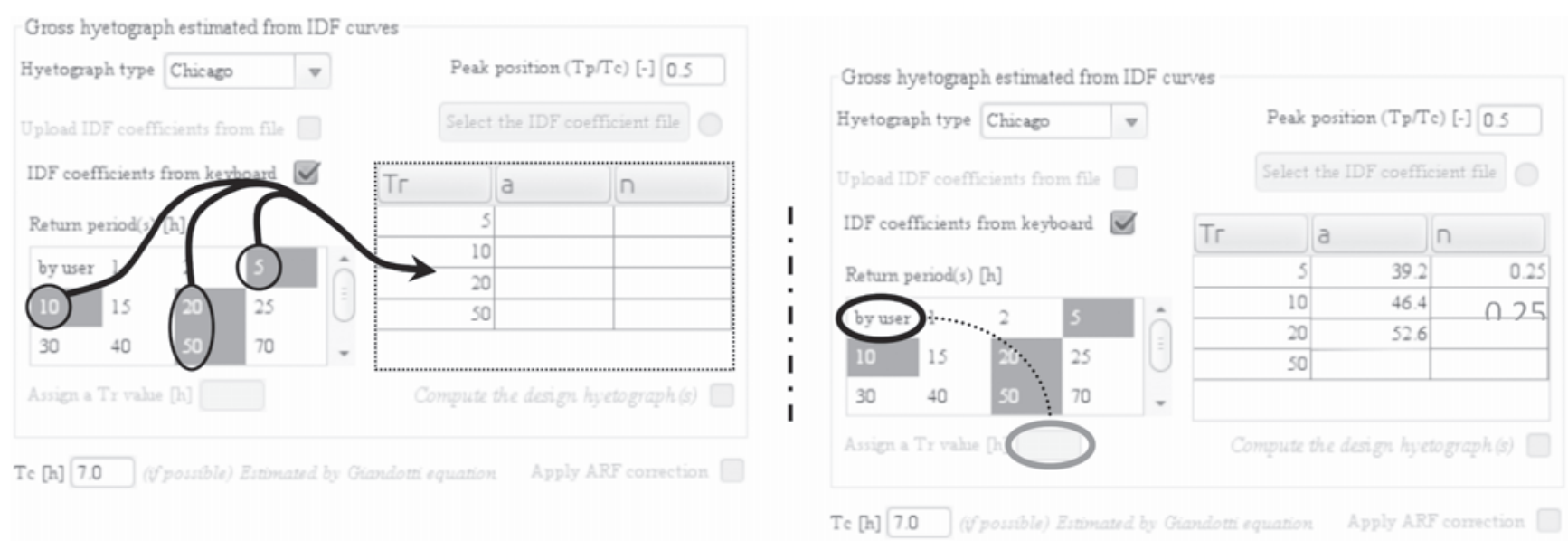

Figure 6. EBA4SUB - Intensity-duration-frequency curves (IDF) parameters assigned using the keyboard and gross hyetograph estimation. 
case study is not to validate the proposed framework but to evaluate its performance when varying primary and secondary parameters. In the following paragraphs, the results of each framework step are illustrated by comparing the design peak discharge values obtained when varying the hyetograph type (rectangular, triangular, or Chicago), the rainfall intensity peak position (at the beginning, middle, and end of the rainfall event: $r_{c}=0,0.5$, and 1$)$, and the return period $(5,10,20$, and 50 years). Moreover, the outputs are compared with the rational formula results.

The watershed DEM at a $20 \mathrm{~m}$ resolution is shown in Figure 10. The main characteristics are listed in Table 2 . The watershed elevations range between $431 \mathrm{~m}$ and $1032 \mathrm{~m}$, while the area is $8.35 \mathrm{~km}^{2}$; the average slope is equal to $32.6 \%$, with a maximum distance between the outlet and the watershed divide equal to $7.67 \mathrm{~km}$. The outlet is selected at the confluence of the Nera river.

Figure 10 shows the soil use map derived by the CLC, the drainage network resulting from EBA4SUB, the hillslope velocity map, and the WFIUH. WFIUH is calibrated so that its centre of mass is equal to the lag time ( $=1.8 \mathrm{~h}$ for the case study).

In this case study, we refer to the Terni rain gauge that is near the investigated watershed and that is associated with IDF curves provided by Centro Polifunzionale Regione Umbria (http://www. cfumbria.it). Table 2 shows the watershed morphometric characteristics, the values of all primary and secondary parameters useful for EBA4SUB and the formula's rational application. The obtained $T_{c}$ value is $2.42 \mathrm{~h}$ but is rounded to $3 \mathrm{~h}$ because the hyetograph resolution is hourly, while the runoff coefficient is the average value of the CORINE soil use map using empirical and common tables (Chow et al., 1988). Interestingly, either the channel or the hillslope velocity values are sufficiently realistic.

Table 3 reports the values of the IDF parameters while varying the return periods, as well as the values of the net cumulative rainfall estimated with the $\mathrm{CN}$ method; this information is invariant for all analysed hyetographs.

Figure 11 shows the gross and net hyetographs and design hydrographs obtained with the seven-parameter combinations related to the 50 -year return period. The plots confirm that the peak discharges vary when different hyetographs are used as input and that the Chicago type

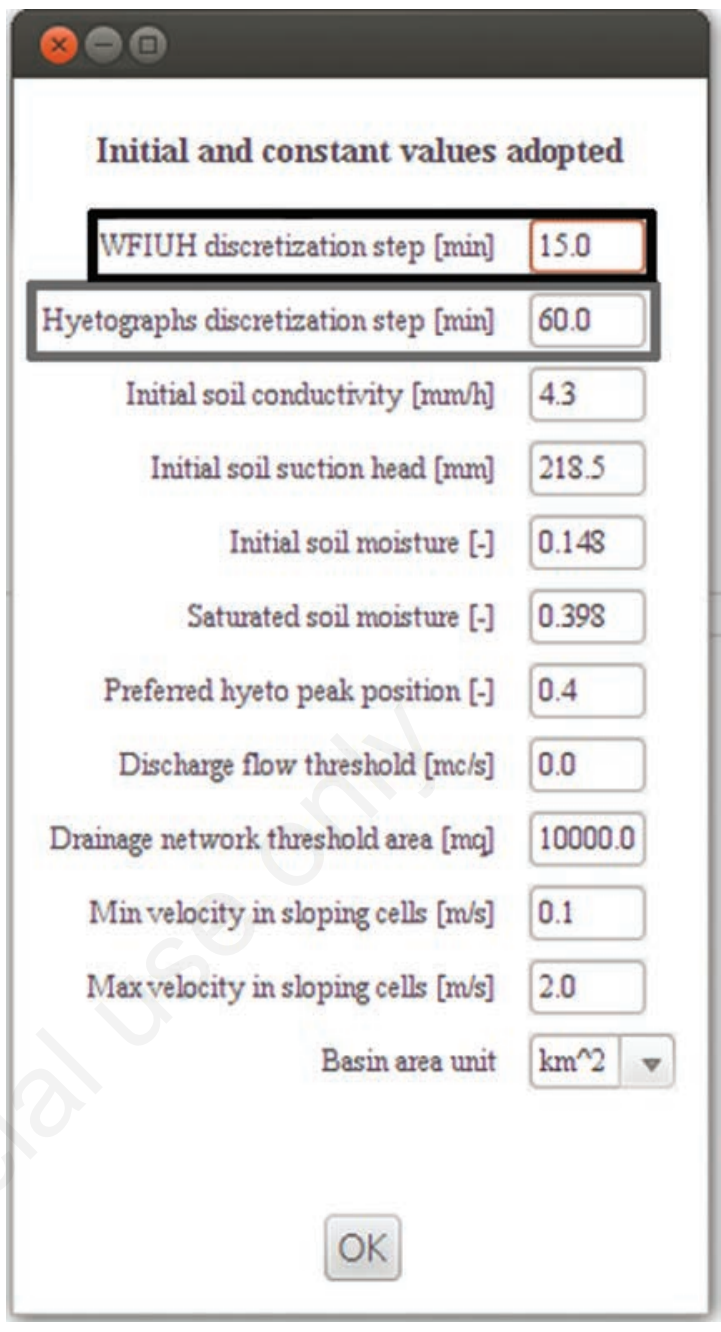

Figure 7. EBA4SUB - Basic parameter mask.

Table 1. EBA4SUB - primary and secondary EBA4SUB parameter list.

\section{Primary parameters}

$T_{c} \quad$ Concentration time

Initial losses fraction

\begin{tabular}{ll} 
& Initial losses fraction \\
\hline $\mathrm{CN}$ & Curve number
\end{tabular}

\section{Secondary parameters}

$K_{s} \quad$ Saturated hydraulic conductivity

$\theta_{i} \quad$ Initial value of soil water content

$\theta_{s} \quad$ Field saturated soil water content

$h_{f} \quad$ Matric pressure head at the moving wetting front

$v_{\text {hmin }} \quad$ Minimum velocity for hillslope cells

$v_{\text {hmax }} \quad$ Maximum velocity for hillslope cells

At Threshold area for river network

$D t_{p} \quad$ Hyetograph time discretisation

$D t_{\text {iuh }} \quad$ WFIUH and hydrograph time discretisation

WFIUH, the instantaneous unit hydrograph based on the width function; CN4GA, curve number for Green-Ampt.
It sets the critical rainfall duration and its cumulative depth.

It determines the WFIUH dispersion. It is estimated by the Giandotti formula.

It sets the initial losses as percentage of the potential retention of soil. Default value is 0.2 . Such value cannot be modified if the original $\mathrm{CN}$ tables are employed.

It sets the net cumulative rainfall depth. It is assigned using empirical tables. 
Table 2. Initial values of the EBA4SUB parameter and case study summary.

\begin{tabular}{|c|c|c|c|}
\hline IUH timestep (min) & 15 & DEM cell size & 20 \\
\hline Hyetograph step (min) & 60 & Basin area $\left(\mathrm{km}^{2}\right)$ & 8.35 \\
\hline Average soil type & Sandy clay loam & Min. elevation (m) & 140 \\
\hline Initial soil conductivity (mm/h) & 4.3 & Mean elevation (m) & 431.1 \\
\hline Initial soil suction head (mm) & 218.5 & Max. elevation (m) & 1032 \\
\hline Initial soil moisture (-) & 0.148 & Mean slope (\%) & 32.6 \\
\hline Saturated soil moisture (-) & 0.398 & Maximum divide-outlet distance $(\mathrm{km})$ & 7.67 \\
\hline Discharge network threshold area $\left(\mathrm{km}^{2}\right)$ & 0.5 & Average curve number (-) & 69.6 \\
\hline Min. velocity hilslope cells (m/s) & 0.05 & $\lambda(-)$ & 0.2 \\
\hline Max. velocity hillslope cells (m/s) & 0.5 & $\mathrm{AMC}$ & II \\
\hline Calibrated channel velocity (m/s) & 0.65 & Hydrologic soil group & B \\
\hline Average velocity hillslope cells (m/s) & 0.38 & Average C index (-) & 0.301 \\
\hline
\end{tabular}

IUH, instantaneous unit hydrograph; DEM, digital elevation model; AMC, antecedent moisture condition.

\section{$\otimes \Theta 0$}

Initial and constant values adopted

WFIUH discretization step [min] 15.0 Hyetographs discretization step [min] 60.0

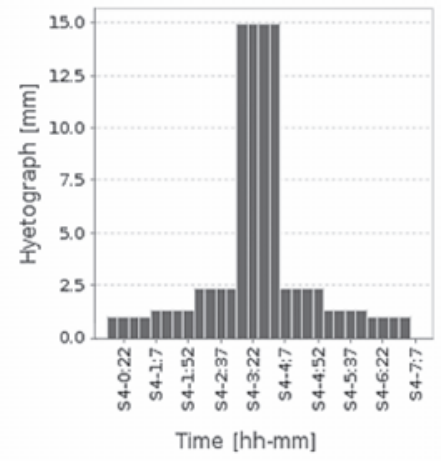

\section{QO०}

Initial and constant values adopted

WFIUH discretization step [min] 60.0

Hyetographs discretization step [min] 60.0

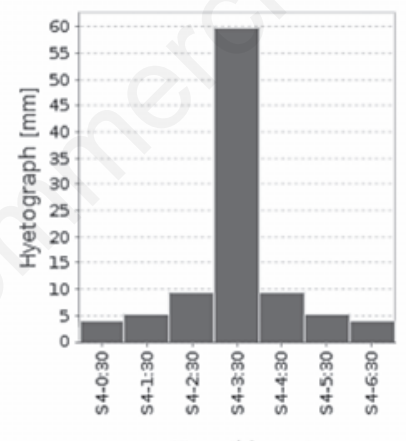

\section{Q⿻日,}

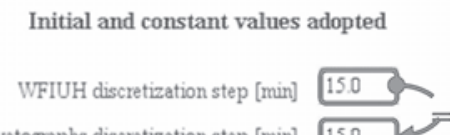
Hyetographs discretization step [min] 15.0

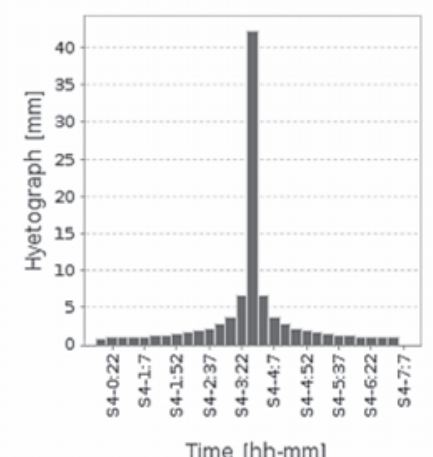

Figure 8. EBA4SUB - Options for the gross rainfall temporal resolution.

Topography, Land use, and soil type
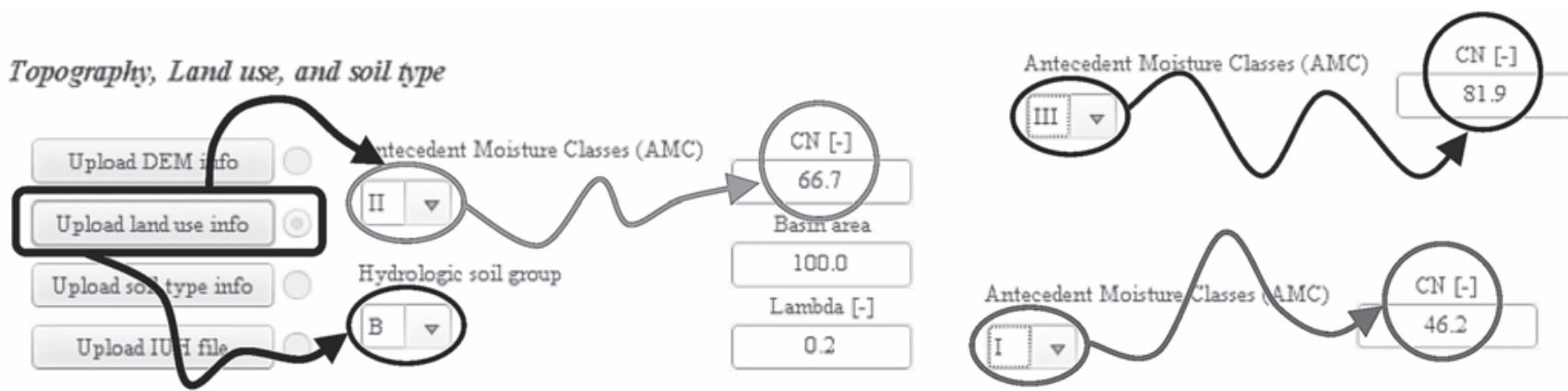

Figure 9. Parameter set up for curve number $(\mathrm{CN})$ evaluation. 
produces the maximum values. The plots also confirm that the peak discharges are invariant when varying the peak position, which has a secondary role; a value of 0.5 is appropriate. Moreover, when using non-rectangular hyetographs and infiltration equations for net rainfall estimations, the gross rainfall could stop after the hydrograph peak, suggesting that a shorter event would be more critical. This apparent overestimation of the critical duration is compensated for the non-rectangular shape of the design hyetograph.

Finally, Figure 12 summarises the design peak discharge values for all options and compares them with the rational formula values.

Based on the graph, the following can be concluded. As expected, when increasing the return period, the difference among the results obtained using different hyetographs increases and confirms the tendency of the Chicago hyetograph to provide higher values. Moreover, the peak position leads to limited variability, so it is almost not influent compared with the primary parameters.

The rational formula results usually provide lower values compared with EBA4SUB. In the present case study, it is clear that the $\mathrm{CN}$ and the $C$ cause the differences in the final results. Additionally, the rational formula tends to underestimate the discharge for high return periods; actually, by increasing the return period, the discharge slightly increases in an unrealistic manner (only $42 \%$ from 5 to 50 years). By increasing the total gross rainfall (for high return periods), the percentage of runoff $(30.1 \%)$ is the same; most likely, the losses are overestimated.

\section{Conclusions}

The design hydrograph estimation for small and ungauged watersheds is particularly complex. If the watershed is not included in an area where it is possible to apply regionalisation approaches, then the practitioner is limited to using empirical methodologies. Until now, the rational formula has been preferred for its simplicity or paucity of input parameters. Recently, the authors have proposed an event-based model that makes it possible to estimate either the design peak discharge or the entire design hydrograph using the same input parameters used by the rational formula. The model, named EBA4SUB, combines a set of common modules of the rainfall-runoff transformation and adapts them to empirical practical cases where it is not possible to calibrate the model parameters.
In this work, the software EBA4SUB that implements the homonymous model is introduced. The software is designed with the aim of being user-friendly and fast, allowing for the application of the EBA4SUB framework and classical rainfall-runoff models. The procedure is divided in the design hyetograph step, for which the Chicago type is suggested, the hyetograph net estimation step, in which a matching procedure that combines the soil conservation service-CN method and Green-Ampt equation is performed, and finally the rainfallrunoff transformation step, for which the instantaneous unit hydrograph based on the width function is adopted and is appropriately designed to avoid parameter calibration.

The main peculiarity of the proposed framework is the optimisation of the morphometric information extracted from the DEM for improving the assumptions of the model parameter values.

The EBA4SUB model includes twelve parameters, nine of which have a secondary role in the sense that the output hydrograph is nearly insensitive to their variability. The residual three parameters (concentration time, curve number, and percentage of initial losses) meaningfully influence the final output; these parameters should be calibrated when observations are available.

The proposed case study, to confirm the secondary role of the peak position of the Chicago hyetograph, compared rational formula results. EBA4SUB seems to provide more realistic behaviour of the peak discharge as a function of the return period.

Table 3. Intensity-duration-frequency curves parameters and soil conservation service-curve number net cumulative rainfall.

\begin{tabular}{lccc}
$T_{\mathrm{r}}(\mathrm{y})$ & $\mathrm{a}(\mathrm{mm} / \mathrm{h})$ & $\mathrm{n}(-)$ & $\mathrm{P}_{\mathrm{e}}(\mathrm{mm})$ \\
5 & 32.5 & 0.268 & 3.37 \\
10 & 36.8 & 0.268 & 5.23 \\
\hline 25 & 42.2 & 0.268 & 7.99 \\
50 & 46.3 & 0.268 & 10.38 \\
\hline
\end{tabular}

$T_{r}(y)$, return period in years; a, n, intensity-duration-frequency coefficients; $P_{e}$, total net rainfall.
A

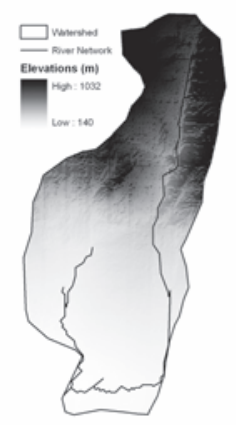

B

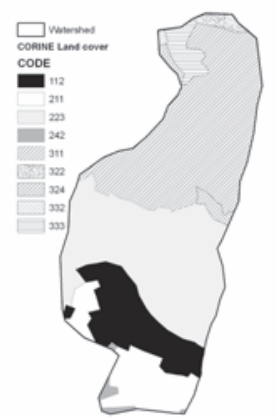

C

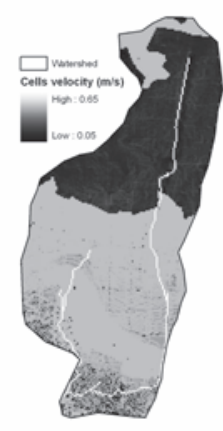

D

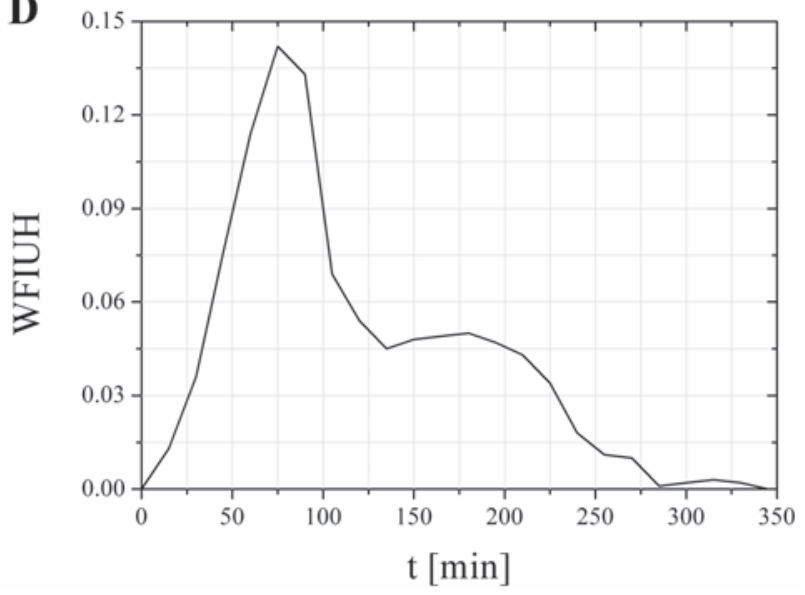

Figure 10. A) Digital elevation model and drainage network; B) CORINE soil use code; C) hillslope velocities (m/s); and D) the instantaneous unit hydrograph based on the width function (WFIUH). 

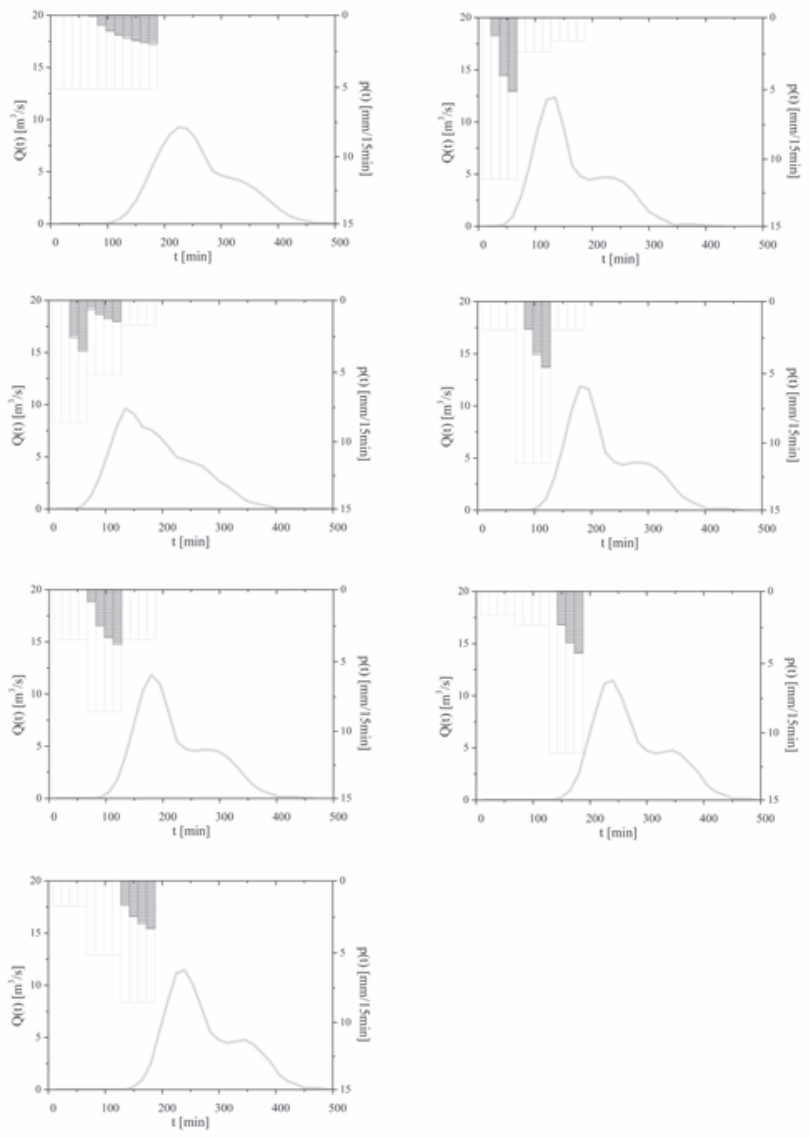

Figure 11. Gross hyetograph, net hyetograph and design hydrograph estimated for a 50 -year return period.

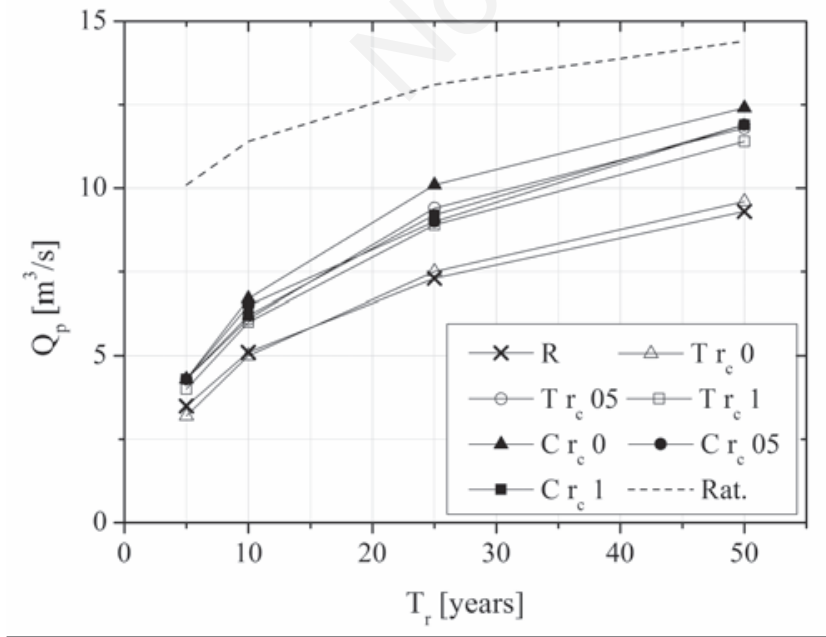

Figure 12. Return period/peak discharge $\left(\mathrm{m}^{3} / \mathrm{s}\right)$. Hyetograph type: $\mathrm{R}$, rectangular; $T$, triangular; and $\mathrm{C}$, Chicago. rc $0,0.5,1$ are the peak positions in the hyetograph at the beginning, middle and end of the synthetic event. Rat., rational formula.

\section{References}

Alfieri L., Laio F., Claps P. 2008. A simulation experiment for optimal design hyetograph selection. Hydrol.l Process. 22:813-20.

Autorità di Bacino del Fiume Tevere. 2006. PAI - Piano stralcio di assetto idrogeologico. Available from: http://www.abtevere.it/node/88

Bloschl G., Sivapalan M., Wagener T., Viglione A., Savenije H. 2013. Runoff prediction in ungauged basins - synthesis across processes, places and scales. Cambridge University Press, Cambridge, UK.

Boni G., Ferraris L., Giannoni F., Roth G., Rudari R., 2007. Flood probability analysis for un-gauged watersheds by means of a simple distributed hydrologic model. Adv. Water Resour. 30:2135-44.

Borga M., Boscolo P., Zanon F., Sangati M. 2007. Hydrometeorological analysis of the 29 August 2003 flash flood in the eastern Italian Alps. J. Hydrometeorol. 8:1049-67.

Chow V.T., Maidment D.R., Mays L.W. 1988. Applied hydrology. McGraw Hill, New York, NY, USA.

Dhakal N., Fang X., Cleveland T.G., Thompson D.B., Asquith W.H., Marzen L.J. 2012. Estimation of volumetric runoff coefficients for Texas watersheds using land-use and rainfall-runoff data. J. Irrig. Drain. Eng. 138:43-54.

Giannoni F., Smith J.A., Zhang Y., Roth G., 2003. Hydrologic modeling of extreme floods using radar rainfall estimates. Adv. Water Resour. 26:195-203.

Green W.H., Ampt G.A. 1911. Studies on soil physics. J. Agric. Sci. 4:1-24.

Grimaldi S., Petroselli A. 2015. Do we still need the rational formula? An alternative empirical procedure for peak discharge estimation in small and ungauged basins, Hydrol. Sci. J. 60:66-7.

Grimaldi S., Petroselli A., Nardi F. 2012a. A parsimonious geomorphological unit hydrograph for rainfall-runoff modelling in smallungauged basins. Hydrol. Sci. J. 57:73-83.

Grimaldi S., Petroselli A., Nardi F., Alonso G. 2010. Flow time estimation with variable hillslope velocity in ungauged basins. Adv. Water Resour. 33:1216-23.

Grimaldi S., Petroselli A., Romano N. 2013a. Curve-number/Green-Ampt mixed procedure for streamflow predictions in ungauged basins: parameter sensitivity analysis. Hydrol. Process. 27:1265-75.

Grimaldi S., Petroselli A., Romano N. 2013b. Green-Ampt curve number mixed procedure as an empirical tool for rainfall-runoff modelling in small and ungauged basins. Hydrol. Process. 27:1253-64.

Grimaldi S., Petroselli A., Tauro F., Porfiri M. 2012b. Time of concentration: a paradox in modern hydrology. Hydrol. Sci. J. 57:217-28.

Hrachowitz M., Savenije H.H.G., Blöschl G., McDonnell J.J., Sivapalan M., Pomeroy J.W., Arheimer B., Blume T., Clark M.P., Ehret U., Fenicia F., Freer J.E., Gelfan A., Gupta H.V., Hughes D.A., Hut R.W., Montanari A., Pande S., Tetzlaff D., Troch P.A., Uhlenbrook S., Wagener T., Winsemius H.C., Woods R.A., Zehe E., Cudennec C. 2013. A decade of predictions in ungauged basins (PUB) - a review. Hydrol. Sci. J. 58:1198-55.

Keifer C.J., Chu H.H. 1957. Synthetic storm pattern for drainage design. ASCE J. Hydraul. Div. 83:1-25.

Kuichling E. 1889. The relation between the rainfall and the discharge of sewers in populous areas. Trans. Am. Soc. Civil Engine. 20:1-56.

Leclerc G., Schaake J.C. 1972. Derivation of hydrologic frequency curves. Report 142. Mass. Inst. of Technol., Cambridge, MA, USA.

Mein R.G., Larson C.L. 1973. Modeling infiltration during a steady rain. Water Resour. Res. 9:384-94.

Mesa O.J., Mifflin E.R. 1986. On the relative role of hillslope and network geometry in hydrologic response. In: V.K. Gupta, I. RodriguezIturbe, and E.F. Wood (ed.), Scale problems in hydrology. D. Reidel, Dordrecht, The Netherlands, pp 1-17.

Mulvaney T.J. 1851. On the use of self-registering rain and flood gauges in 
making observations of the relations of rainfall and flood discharges in a given catchment. Proc. Inst. Civil Engine. Ireland 4:19-31.

Nardi F., Grimaldi S., Santini M., Petroselli A., Ubertini L. 2008. Hydrogeomorphic properties of simulated drainage patterns using digital elevation models: the flat area issue. Hydrol. Sci. J. 53:1176-93.

NRCS (Natural Resources Conservation Service). 2008. National engineering handbook - part 630, Hydrology. U.S. Department of Agriculture, Washington, DC, USA.

Petroselli A., Grimaldi S. 2015. Design hydrograph estimation in small and fully ungauged basins: a preliminary assessment of the EBA4SUB framework. J. Flood Risk Manage. [In press].

Rinaldo A., Marani A., Rigon R. 1991. Geomorphological dispersion.
Water Resour. Res. 27:513-25.

Sivapalan M., Takeuchi K., Franks S.W., Gupta V.K., Karambiri H., Lakshmi V., Liang X., McDonnell J.J., Mendiondo E.M., O'Connell P.E., Oki T., Pomeroy J.W., Schertzer D., Uhlenbrook S., Zehe E. 2003. IAHS decade on predictions in ungauged basins (PUB), 20032012: shaping an exciting future for the hydrological sciences. Hydrol. Sci. J. 48:857-80.

Woodward D.E., Hoeft C.C., Hawkins R.H., Van Mullem J., Ward T.J. 2010. Discussion of "Modifications to SCS-CN method for longterm hydrologic simulation” by K. Geetha, S. K. Mishra, T. I. Eldho, A. K. Rastogi, and R. P. Pandey. J. Irrig. Drain. Eng. 136:444-6. 